\title{
Analysis of Promotional Strategies To Improve The Competitiveness Of Woven Fabrics (Case Study of Sasak Tribe Woven Fabric Craftsmen Group in West Nusa Tenggara)
}

\author{
Dr. Udin Ahidin, S.E, M.M.,C.M.A., Dr. Yayan Sudaryana, MM., \\ Dr. Ali Maddinsyah, S.E, MM., Febri Triwahyudi and Ibnu Sina \\ Lecturer of Universitas Pamulang, Tangerang Selatan Banten-Indonesia
}

\begin{abstract}
This case study aims to look at current strategy conditions carried out by craftsmen and managers of cooperatives or arthouse weaving in selling their crafts products. This study also aims to find out how the right promotional strategies to improve the competitiveness of Sasak ethnic handicrafts in West Nusa Tenggara Province.4This research is included in descriptive qualitative research since the author tries to find problems that occur in the sale of Sasak tribe weaving in West Nusa Tenggara. The findings in this study are strengthened by interviews, direct observation, focus group discussions and recording of video and photo documents. The study involved seven respondents who represent each party directly or indirectly involved in a series of production processes to the marketing of Sasak Tribe woven fabrics. The researcher also used a questionnaire to follow up the findings during the focus group discussion. The findings in the discussion focus group of researchers directly input into the questionnaire to be able to see clearer conditions of promotion in order to improve the competitiveness of Sasak Tribe woven fabric and also efforts that can be implemented to maximize its promotion strategy. The resultof this study shows that the condition of the promotion strategy of Sasakethnic woven fabrics can be further enhanced by promoting it more aggressive. Aggressive promotion will increase the competitiveness of Sasak tribe bothin National and International eyes.
\end{abstract}

Keywords: Promotion Strategy, Competitiveness, Sasak Tribe Woven Fabric

\section{Introduction}

The rapid development of the world has a lot of impacts on human life. Uncontrolled population growth makes all aspects of human life also increase. The increasing number of people in the world makes the competition map in life even more competitive. Increasing severity of congestion and the increasingly limited area of work makes the level of stress in humans also experience changes in a higher direction. Individuals who cannot compete in life will be excluded from competition, therefore the development of the world must help develop the quality of human life. Increasing levels of stress in humans are felt to be very disturbing in daily life, therefore recreation or vacationing is felt to be one of the efforts that can be chosen by people to be able to reduce stress levels after a long period of work or routine activities. People make time for a vacation to refresh their mind and energy after a long time doing routine both work and study.

The impact of global changes that occur in the world one of which is the increasing number of tourists both domestic and foreign tourists. Governments in each country are well aware that the tourism sector cannot be underestimated because the tourism industry is a potential industry to be managed and used as a source of state revenue. The tourism industry 
in each country is very well developed because each country has a goal in increasing its source of income. Therefore, each country does not carelessly manage foreign exchange resources, which is very potential in increasing the number of countries. In the era of globalization like this one that is increasing very rapidly is the ability of technology and information. Countries use technology and information enhancement as one of the media to promote the potential of their country so that it can be seen to the international world with the aim of increasing the source of state income because it can attract tourists to visit the country. Advances in technology and information are in line with the ability of each country to promote their country as a country worth visiting, one of which is the use of social media to internationallevel tourism events.

Lombok Island in West Nusa Tenggara Province has become one of the developing tourism destinations in Indonesia with a proven championship in world- class championships. In the event, Indonesia was awarded as the World's Best Halal Tourism Destination (Lombok), World's Best Halal Honeymoon Destination (Lombok), and World's Best Family Friendly Hotel (Sofyan Hotel / Lombok). Since the election of Lombok as one of the world-class halal tourist destinations automatically introducing Indonesia in general to the world arena. By making Lombok a champion in the world halal tourism destination it is hoped that it will also attract tourists who will visit Indonesia, especially to the island of Lombok. With the increasing number of tourists coming to Lombok it is also expected to be able to spread information about Lombok in the international world about the location of tourism and the conditions of the people who inhabit the island of Lombok. Lombok is one of the tourist sites that is quite complete because in addition to having a beautiful island Lombok also has an active volcano and makes Mount Rinjani a part of tourism destinations in Lombok. Tourist destinations in Lombok which are world- famous among them are Gili Trawangan, Pantai Aan, Narmada Park and Mount Rinjani. Rows of other tourist destinations are no less interesting than the place I mentioned earlier so that tourists can choose and visit many interesting places when they are in Lombok.

The Sasak tribe is a tribe that inhabits the island of Lombok and uses the Sasak language. Most Sasak tribes are Muslim. ata Sasak comes from the word sak sak, meaning one one. The word sak is also used by some Dayak tribes on the island of Borneo to say one. Sasak people are known to be good at making cloth by weaving. In the past, every woman would be said to be an adult and ready to settle down if she was good at weaving. Weaving in the Sasak language is Sèsèk. The word sèsèk comes from the word tightness, sneaking or listening. Sèsèk is done by inserting threads one by one (sak sak), then the thread is squeezed or pressed together until it is tight and dense to become a form of fabric by striking the loom. Uniquely the sound that was heard when hitting the loom even then sounded like the sound of a sack and was only done twice. That is the origin of the word Sasak which was later taken as the name of a tribe on the island of Lombok. The Sasak people who originally inhabited the island of Lombok used the Sasak language as a colloquial language. Sasak tribal customs can be witnessed at the wedding reception, where women if they want to be married by a man then the woman must be rushed to his family's home from the man's side, this is known as running away or runaway.

Sasak tribe has a distinctive identity that is as one of the original tribes of Indonesia that still produces art in the form of woven fabrics. Sasak tribe woven cloth is one of the distinctive identities owned by Sasak tribe. Sasak tribe at first did make weaving as a livelihood to meet their daily needs. Until now weaving Sasak tribe is still a superior work of art in West Nusa Tenggara. The work of Sasak tribe weaving has been going down and down between generations. Until now tourists can still see firsthand the production process of 
making woven Sasak tribes that are still sustainable among other handicrafts that are also the livelihood of Sasak tribes besides weaving. Even though the Sasak tribe weaving craft has gone downhill but it does not make the Sasak tribe weaving undergo significant changes. Craftsmen of Sasak tribe weaving still use traditional tools and materials in producing the weaving that they produce. Weaving production is still done manually from selecting raw materials, breaking down, spinning to the process of designing and finishing.

In Lombok, songket woven fabric is fabric that has embossed decoration made from cotton yarn, gold thread, or silver thread. In Bima, songket fabric means fabric decorated with gold or silver threads called Tembe Songke, while cloth decorations that use colored cotton thread are called Tembe Salungka. motifs on traditional Lombok cloth are also varied. This decorative fabric is certainly inseparable from the culture of prehistoric times, Hinduism, and Islam. The decoration and motif also has a variety of symbolic and philosophical meanings.

On the island of Lombok weaving activities are still mostly using traditional (classical) methods. So the loom used is still using materials from wood, how to operate it is also still very manual. Fabric weavers usually sit on the ground on a mat / cloth or in a hall with legs stretched straight forward. The aim is to facilitate them in the process of weaving the cloth. The main reason is that they still use traditional methods of weaving in addition to preserving local customs, culture and wisdom, most of all as a tourist attraction. In fact the theory is really proven able to suck the interest of local and foreign tourists to come and visit. Lombok woven fabric is somewhat unique. Woven fabric motifs that are made are usually in accordance with the wishes of the weaver himself, when weaving the fabric.

In reality the Lombok island weaving creations are not like what should have happened, the work of the Sasak tribe weaving seems to be closed from the magnitude of the name of the natural tourism area on the island of Lombok. Promotional media run by artisans weaving does not keep up with the times. Media promotion of the weaving craftsmen as if they only rely on promotion directly when tourists visit the weaving production site alone makes the Sasak tribe weaving unable to compensate for the promotion of tourist areas that raise the theme of nature as the spearhead. The weaving craftsmen of Sasak tribes only think about how to continue to preserve culture at the production level. This can be seen from how the craftsmen exhibit their finished weaving products which are only displayed in the village of weaving craftsmen. Tourists also lack media information about the excess weaving of Sasak tribes among similar weaving crafts in Indonesia. Weaving craftsmen have not made the most of social media with the potential to inform and market their cultural arts products. The limitations of tools and materials make it one of the other factors that also limits the exploration of weaving crafts. Weaving production also takes a long time because everything is done with their own skilled hands (handmade) so it takes quite a long time to keep up with the flow of fashion fashions that are developing in the community.

Sasak tribe craftsmen should also be able to introduce the results of their products with other media such as advertising media both print advertisements and information technologybased advertisements. By advertising the products made by Sasak tribe, it is expected to become a funnel of information for a wide audience who are not yet familiar with the handicraft weaving to find out the Sasak handicraft and weaving products as the final destination of the promotion. Advertising has an important role to provide extensive information with a short time so that potential buyers can conclude themselves about how the Sasak woven products from the production process to the sales process. In this era of globalization like advertising on social media can be relied on because the global community is already accustomed to looking for references or information about a matter using social media. This step should be observed and taken quickly as a form of the seriousness of the 
craftsmen to promote the craft produced.

Based on the problems that the authors have described above, the focus of the study is as follows: 1) Promotional media that have been utilized by Sasak weaving craftsmen in order to introduce the products of Sasak tribe woven cultural products, 2) Various forms of promotional models in order to introduce Sasak tribe weaving crafts. Problem Identification:

a) What is the condition of the promotion strategy of Sasak woven cloth craft in Lombok Island, West Nusa Tenggara at the moment

b) How to apply a better promotional strategy to increase sales of Sasak woven cloth.

\subsection{Research Purposes}

a) To find out how the conditions of the promotion strategy carried out by Sasak woven cloth craftsmen today

b) To find out how to apply more appropriate promotional strategies to increase sales of Sasak tribe woven fabrics

\section{Literature Review}

\subsection{Definition of Management}

The definition of Marketing Management according to Kotler and Keller (2009: 5) is "The art and science of selecting target markets and reaching, retaining, and growing customers by creating, delivering, and communicating superior customer value." This definition explains that marketing management has the function to determine and increase demand in the market through a process that involves the analysis, planning and implementation and supervision of programs aimed at serving the market in accordance with market needs and desires.

\subsection{Marketing Strategy}

Marketing Strategy (Marketing Strategy) is the process of determining the target market with related marketing mix strategies where:

a) Target Market; is a group of homogeneous customers or markets whose companies want to be served their requests.

b) Marketing Mix ; are the variables compiled by the company in order to satisfy the target market. Marketing Mix is a combination of four variables or activities that are the core of a company's marketing system, namely: products, price structures, promotional activities and distribution channel systems. These marketing mix variables can be used as a basis for taking a strategy in an effort to get a very strategic position in the market.

Marketing strategy is making decisions about marketing costs, marketing mix, marketing allocation in relation to the expected environmental conditions and competitive conditions.

\subsection{Research Propotition}

Based on the literature review, relevant previous research and the framework of thought 
above, the following research propositions are determined:

a) There is a weakness in the implementation of the promotion strategy set by the Sasak weaving craftsmen in the current sales framework.

b) A good promotion strategy will increase competitiveness and increase competitiveness also increase sales of Sasak woven cloth.

\section{Materials and Methods}

This study uses a qualitative approach, namely by emphasizing its analysis on the process of concluding comparisons as well as on an analysis of the dynamics of the relationship of phenomena observed using scientific logic (Azmar: 2001).

\subsection{Location of Research}

In this study the researchers took the location of the study in Sade Hamlet, Rembitan village, Pujut, Central Lombok, West Nusa Tenggara. Sade Hamlet is one of the producers of weaving Sasak tribe. In addition to being a native weaving village of Sasak tribe, Sade Hamlet is a tourist village for local and international tourists who want to know more about the original life of the Sasak tribe from the building where they live to the habits of their daily lives.

\subsection{Data Collection}

To obtain accurate data that can be trusted the truth and relevant issues to be studied, then the data collection can be done by several methods such as interviews, observation, Focus Group Discussion, documents, and triangulation. The method used in this research is a descriptive method in the form of case studies of the potential promotion strategies of Sasak tribe weaving by collecting data and information from various sources to answer existing problems. Data analysis conducted by this research was descriptive analysis, space matrix analysis, and SWOT analysis

\section{Results}

The promotion strategy of Sasak woven cloth craft in Lombok Island, West Nusa Tenggara, is currently in quadrant 1 , which means that it supports an aggressive strategy. To support an aggressive strategy, all parties involved in the Sasak weaving craft must be more aggressive or aggressive in marketing their products, due to the following matters:

a) Motifs or patterns and basic colors are the main attraction of Sasak woven cloth The quality of the material and woven are taken into consideration before buying weaving

b) Weaving has other functions, in addition to clothing fabrics, woven cloth can also be used as a basic material for making curtains, tablecloths or bed covers

c) Cooperatives or arthouses also contribute well to weaving craftsmer.

d) Travel services help increase tourist visits to Sasak Tribe weaving craft centers

e) Lombok NTB regional government also promotes Sasak weaving crafts in various government activities, 
Online shop opens great opportunities to increase promotion and sales of Sasak woven cloth

Implementation of a better promotional strategy to increase sales of Sasak woven cloths can be done as follows:

1) The NTB government must play an active role in promoting the great potential that exists in its territory;

2) Providing detailed product information is very important because not everyone knows the details of the product being sold, maybe even many people who are not familiar with the Sasak weaving craft. It is hoped that the results of regional cultural heritage will increase sales of Sasak weaving handicraft products.

3) The cooperative / arthouse manager provides a direct explanation to visitors about the quality of fabrics.

4) Travel service managers make Sasak tribe weaving as a uniform or souvenir for their service users.

5) Giving discounts or discounts for buyers both buyers from cooperatives / arthouses and online shops.

6) Cooperatives / Art houses open sales branches in potential shopping areas such as nature tourism areas and in the city center.

7) The government provides education in terms of packaging products especially woven fabrics to craftsmen and managers of cooperatives / art houses in order to increase the selling value of woven products.

8) The government immediately registered the copyright to the weaving pattern so that it would not be copied by irresponsible parties.

9) Promote promotion of the function of the Sasak tribe woven fabric which emphasizes that the Sasak tribe woven fabric has a multi function, in addition to being used as clothing material, woven fabric can also be used as table decorations, bedcovers, curtains and etc.

10) The government must provide ongoing training in woven fabric crafts, both workmanship, packaging, marketing techniques and improving the quality of weaving.

11) Woven craftsmen must create several sizes of woven cloth so that people can choose woven fabric according to their needs, which will affect the price of woven fabric products.

12) Some of the craftsmen of weaving are empowered to make other products with basic materials of woven cloth such as clothes, scarves, skirts and so on. Various types of weaving products are useful to deal with changes in people's taste in clothing.

13) The government provides tools for the packaging process of woven products to facilitate craftsmen in marketing and can also increase the selling value of products.

\section{Refferences}

[1] Departemen Pendidikan dan Kebudayaan, Dampak Modernisasi Terhadap Hubungan Kekerabatan di Nusa Tenggara Barat, (Nusa Tenggara Barat: Depdikbud, 1985), hal 15-16

[2] Amstrong, Gary \& Philip, Kotler. 2002. Dasar-dasar Pemasaran. Jilid 1, Alih Bahasa Alexander Sindoro dan Benyamin Molan. Jakarta: Penerbit Prenhalindo. 
[3] Azmar, Saifuddin (2001) Metode Penelitian, Yogyakarta: Pustaka Pelajar Offset. Charles W. Lamb, Joseph F. Hair, Carl Mcdaniel. 2001. Pemasaran. Edisi Pertama, Salemba Empat, Jakarta.

[4] Chris, Barker. 2009. Cultural Studies: Teori \& Praktik. Bantul: Kreasi Wacana. David, Fred R. 2006. Manajemen Strategi. Buku 1, Edisi kesepuluh. Jakarta : Salemba Empat

[5] Fill, Chris. (2009). Marketing communications: Interavtivity, communities, and content $5^{\text {th }}$ edition, England: Pearson Education Limited.

[6] Freddy Rangkuti, 2008, The Power Of Brands, Jakarta : Penerbit Gramedia

[7] Fred R. David. Manajemen Strategis Konsep. Buku 1. Edisi 12. (Jakarta: Salemba Empat, 2011), h. 145

[8] Gitosudarmo, Indriyo. 2008. Manajemen Pemasaran, edisi pertama, cetakan keempat. BPFE: Yogyakarta.

[9] Glueck, William F. dan Jauch, Lawrence R. Manajemen Strategis dan Kebijakan Perusahaan. Jakarta: Erlangga, 1994.

[10] Handoko, T Hani. 2001. Manajemen Personalia dan Sumberdaya Manusia,Edisi Kedua. BPFE, Yogyakarta.

[11] Hasibuan, Malayu. S.P. 2009. Manajemen: Dasar, Pengertian Dan Masalah Edisi Revisi: Jakarta: Bumi Aksara.

[12\} Husein Umar. Dan Sugiyono 2002. Metode Penelitian Bisnis. Bandung: Alfabeta

[13] Indriyo Gitosudarmo, 2008, Manajemen Pemasaran, edisi pertama, cetakan keempat, Penerbit : BPFE - Yogyakarta

[14] Kotler dan Keller, 2007. Manajemen Pemasaran, Edisi 12, Jilid 1, PT.Indeks, Jakarta.

[15] Kotler, Philip dan Kevin Lane Keller. 2009. Manajemen Pemasaran. Edisi 13 Jilid 2. Jakarta : Erlangga

[16] Lalu Lukman, dkk. 1978. Sejarah Daerah Nusa Tenggara Barat. Jakarta: Proyek Penelitian dan Pencatatan Kebudayaan Daerah-Depdikbud.

[17] Lawrence R., Glueck, William F. (1994). Manajemen strategis dan kebijakan perusahaan, 3rd Edition. Erlangga. Jakarta.

[18] Lupiyoadi, Rambat. 2001. Manajemen Pemasaran Jasa. Jakarta : PT. Salemba Empat.

[19] Machfoedz, Mahmud. 2010. Komunikasi pemasaran modern. Yogyakarta: cakra ilmu Michael E. Porter (1995): “Competitive Advantage"New York: The Free Press., edisi terjemahan (2008)., Kharisma Publishing Group.

[20] Michel E. Porter. Keunggulan Bersaing Menciptakan dan Mempertahankan Kinerja Unggulan. (Jakarta Barat: Binarupa Aksara, 1994), h. 91

[21] Muhardi,. 2007. Strategi Operasi Untuk Keunggulan Bersaing. Yogyakarta:Garaha Pustaka.

[22] Moekijat, 2000. Kamus Manajemen. Bandung : Penerbit CV. Mandar Maju

[23] Peter, J. Paul dan Donnelly. James H. (2011). Marketing Manajemen: Knowledge and skills tenth edition. New York: Mc Graww Hill.

[24] Porter, Michael E. (1995): “Competitive Advantage”New York: The Free Press., edisi terjemahan (2008)., Kharisma Publishing Group.

[25] Prastowo,Andi. (2012). Panduan Kreatif Membuat Bahan Ajar Inovatif. Yogyakarta: Diva Press.

[26] Prof.Dr.Sugiyono. (2004). Metode Penelitian Bisnis. Alfabeta, CV. Bandung

[27] Prof. Dr. Sugiono. (2011). Metode penelitian pendidikan (pendekatan Kuantitatif, kualitatif, dan R\&D); alfabeta. Bandung

[28] Ranupandojo, H., dan Suad Husnan, 2002, Manajemen Personalia, Yogyakarta: BPFE.

[29] Safroni, Ladzi. 2012. Manajemen dan Reformasi Pelayanan Publik dalam Konteks Birokrasi Indonesia. Surabaya : Aditya Media Publishing chein, 2008. Budaya Organisasi, (http://www.majalahpendidikan.com/2011/04), diakses tanggal 6 Februari 2018

[30] Sigit, Suhardi 2007. Marketing Praktis. Cetakan Pertama. Yogyakarta:Penerbit Liberty.

[31] Solomon dan Elnora, (2003), Strategi Pemasaran, Jakarta: Kelompok Gramedia. 